\title{
Topiramate for smoking cessation: Systematic review and meta-analysis
}

\author{
Nesma Lotfy', Hozaifa Elsawah', Mona Hassan
}

\begin{abstract}
INTRODUCTION Topiramate is an antiepileptic drug that has been used for many labeled and off-labeled indications. It may be useful in reducing withdrawal symptoms of various addictive agents such as alcohol, cocaine, cannabis and smoking. To date, some studies have examined the effectiveness of topiramate for smoking cessation. The present review aims to synthesize the results from those studies and determine topiramate effectiveness in smoking cessation.

METHOdS A comprehensive search was conducted in the databases: PubMed/ Medline, Cochrane, Egyptian Knowledge Bank, and Google Scholar. All clinical trials that examined the effect of topiramate, compared with the placebo, on smoking cessation rate were included. Statistical analysis using fixed effect models, heterogeneity and sensitivity analysis were conducted using RevMan 5.3. RESULTS Five trials met the inclusion criteria and were included in the metaanalysis. Topiramate non-significantly increased prolonged smoking abstinence rate $(\mathrm{OR}=1.19,95 \% \mathrm{CI}: 0.57-2.5)$ compared with the placebo. On the other hand, topiramate significantly increased the abstinence rate at weeks $4,6,8$ and $12(\mathrm{OR}=3.07,95 \%$ CI: $1.19-7.93$; OR=4.03, 95\% CI: $1.98-8.2 ; \mathrm{OR}=2.29,95 \%$ CI: $1.23-4.28$; and $\mathrm{OR}=2.45,95 \%$ CI: $1.37-4.39$; respectively) compared with the placebo.

concLusions Based on the five trials, where publication bias cannot be excluded, the current evidence is not sufficient to show a significant difference to favor topiramate in prolonged smoking cessation over the placebo, although the 12th week point prevalence favored topiramate.
\end{abstract}

\section{AFFILIATION \\ 1 High Institute of Public Health, Alexandria University, Alexandria, Egypt \\ CORRESPONDENCE TO Nesma Lotfy. High Institute of Public Health, Alexandria University, 165 El-Horeya Road, Alexandria Governorate, Egypt. E-mail: califora9@gmail.com}

\section{KEYWORDS}

smoking cessation, meta-analysis, topiramate, abstinence rate

Received: 21 September 2019 Revised: 4 December 2019 Accepted: 9 December 2019

\section{INTRODUCTION}

Smoking is a major worldwide health problem that has serious impact on individuals and public health. In the US, smoking causes more deaths every year than the human immunodeficiency virus (HIV), illegal drug use, motor vehicle injuries and firearmrelated incidents ${ }^{1}$. Smoking causes about $90 \%$ of all lung cancer deaths and about $80 \%$ of all deaths from chronic obstructive pulmonary disease (COPD) ${ }^{2}$. According to the World Health Organization's 2013 standardized estimate of smoking prevalence,
$40.5 \%$ of men, $0.3 \%$ of women, and $20.3 \%$ of Egypt's population overall, are daily tobacco smokers. Because of limited agents for smoking cessation, research is being conducted on the available drugs used. One of these is topiramate. Topiramate is an antiepileptic drug used for many indications such as epilepsy ${ }^{3}$, mood stabilization ${ }^{4}$, eating disorders ${ }^{5}$ and migraine prophylaxis $^{6}$. Studies have been increasing regarding topiramate use for various addictions such as cocaine, alcohol and cannabis ${ }^{7-9}$. A few clinical trials have been conducted on the effect of topiramate on smoking 
cessation but they did not have enough power to show superiority of topiramate over the placebo, although some studies showed a numerical difference. Thus, a meta-analysis is required to get more power and clarify the true effect of the drug. The objective of this study was to determine the effectiveness of topiramate in assisting smoking cessation.

\section{METHODS}

\section{Search strategy and selection criteria}

A comprehensive internet search was conducted in March 2019 using the following databases: PubMed/ Medline, Cochrane, Egyptian Knowledge Bank, and Google Scholar. There were no restrictions regarding language or publication date. A Boolean search was conducted using the following search string: [topiramate] AND [smok* OR cigarettes OR tobacco]. The search was adjusted to suit each of the chosen search engines and databases. Once the search was completed, duplications were removed and we elected to include only clinical trials that examined the effect of oral topiramate compared with the placebo on smoking cessation rates in adult smokers. Two of the authors (HE and NL) screened all articles obtained from the search, based on title and abstract, to get all relevant articles for full-text consideration. Any disagreement was resolved by discussion.

\section{Definition of outcomes}

\section{Data extraction}

Data from each study were extracted independently by two authors (HE and NL) regarding the following: study methodology, sample size, type of the population, topiramate dose and duration, comparators, time and setting of the study. Additionally, smoking abstinence rate as a point or period prevalence was extracted.

\section{Clinical trial quality assessment}

The Consolidated Standards of Reporting Trials (CONSORT) 2010 check-list was used to assess the quality of clinical trials ${ }^{10}$.

\section{Risk of bias assessment}

The Cochrane collaboration tool for assessing risk of bias was used for the included studies ${ }^{11}$. This tool consists of seven domains: sequence generation (selection bias), allocation sequence concealment (selection bias), blinding of participants and personnel (performance bias), blinding of outcome assessment (detection bias), incomplete outcome data (attrition bias), selective outcome reporting (reporting bias) and other potential sources of bias. It was assessed independently by two authors (HE and NL).

\section{Statistical methods}

Considering the prolonged (4-week) smoking abstinence rate, the number of smokers that quit smoking was extracted from each study, while the point smoking abstinence rate was extracted from graphs using the specific software 'GetData Graph Digitizer' and then an all time-points meta-analysis $(\mathrm{ATM})^{12}$ was conducted to assess evidence at every time-point reported by the included studies. The overall effect size pooled OR was estimated using a Mantel-Haenszel fixed effect method, with 95\% confidence intervals, and heterogeneity test using the Q statistic. Sensitivity analysis was conducted by excluding the low-quality studies. Due to the small number of included studies, the publication bias and subgroup analysis could not be conducted. The analysis was conducted using RevMan 5.3.

\section{RESULTS}

\section{Search results}

A total of 178 studies were identified from the search, after duplication removal. After title and abstract screening, 164 studies were removed, and the remaining 14 studies were assessed for eligibility based on inclusion criteria. Only 5 studies were eligible for systematic review and meta-analysis (Figure 1). Table 1 shows the reasons for exclusion of some articles in the final stage.

\section{Characteristics of included studies}

The five included studies involved 447 participants at baseline, 220 for topiramate treatment, and 227 as control. The age of the participants ranged from 18 to 70 years and the majority of participants were males recruited from the community. Topiramate was used orally with an initial small dose, titrated gradually up to $300 \mathrm{mg} /$ day, except for one study ${ }^{13}$ that started with $200 \mathrm{mg} /$ day and stopped gradually. The duration of topiramate ranged from 8 to 12 weeks. Carbon monoxide confirmation for smoking abstinence was done in 3 studies, while in the other 2 studies the abstinence was based on self-reporting ${ }^{13,14}$. Table 2 
Figure 1. PRISMA flow diagram for identification and screening of studies

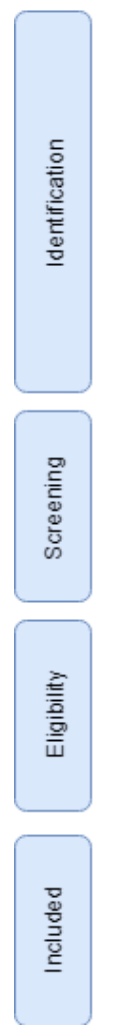

shows the characteristics of the included studies.

\section{Risk of bias among the included studies}

Random sequence generation, performance and

\section{Table 1. Excluded studies and reasons}

\begin{tabular}{|c|c|}
\hline Study & Reason for exclusion \\
\hline Weinberger et al. $2008^{31}$ & $\begin{array}{l}\text { Abstinence rate was not reported. Only } \\
\text { co level was reported }\end{array}$ \\
\hline Vaughan et al. $2014^{32}$ & $\begin{array}{l}\text { The intervention was topiramate with } \\
\text { amphetamine salt }\end{array}$ \\
\hline Baltieri et al. $2009^{28}$ & $\begin{array}{l}\text { Abstinence rate was not reported, } \\
\text { number of cigarettes was reported } \\
\text { instead }\end{array}$ \\
\hline Campayo et al. $2008^{33}$ & The outcomes were not reported \\
\hline Reid et al. $2007^{34}$ & $\begin{array}{l}\text { Nicotine withdrawal symptoms were } \\
\text { measured }\end{array}$ \\
\hline Worley et al. $2018^{30}$ & $\begin{array}{l}\text { Smoking abstinence rate was not } \\
\text { reported, number of cigarettes was } \\
\text { reported instead }\end{array}$ \\
\hline Sofuoglu et al. $2006^{35}$ & Topiramate was used with IV nicotine \\
\hline Isgro et al. $2015^{29}$ & $\begin{array}{l}\text { Abstinence rate was not reported. } \\
\text { Number of cigarettes was reported } \\
\text { instead }\end{array}$ \\
\hline Khazaal et al. $2006^{36}$ & No control group was used \\
\hline
\end{tabular}

detection bias were low in all studies, except for one study $^{13}$. On the other hand, the allocation concealment presented an unclear risk of bias among all studies, except for one study ${ }^{15}$. Regarding attrition bias, there was an unclear risk of bias in one study ${ }^{16}$, while the remaining showed low risk. More details are presented in the Supplementary file.

\section{Outcomes}

Four studies were used to assess point smoking abstinence rate $\mathrm{e}^{13-15,17}$ and three studies were used to assess the prolonged (4-week) smoking abstinence rate $^{15-17}$. None of the three studies achieved a statistically significant effect for topiramate compared with the placebo. Combining the results of the three studies (Figure 2) provides a pooled odds ratio $(\mathrm{OR}=1.19,95 \%$ CI: 0.57-2.5) implying that smokers who were given topiramate had no significantly higher rates on 4-week abstinence from smoking than for the placebo. The $Q$ statistic did not show significant heterogeneity $\left(\chi^{2}=2.85 ; \mathrm{p}=0.240 ; \mathrm{I}^{2}=30 \%\right)$.

\section{Point smoking abstinence rate outcome}

It was found that the pooled odds ratios of smoking 
Table 2. Characteristics of included studies

\begin{tabular}{|c|c|c|c|c|c|c|c|}
\hline \multirow[t]{2}{*}{ Author } & \multirow[t]{2}{*}{ Vethods } & \multirow[t]{2}{*}{ Participants } & \multicolumn{3}{|c|}{ Intervention } & \multicolumn{2}{|c|}{ Outcomes } \\
\hline & & & Duration & Topiramate & Control & $\begin{array}{c}\text { Prolonged } \\
\text { AR }\end{array}$ & Point AR \\
\hline $\begin{array}{l}\text { Anthenelli et } \\
\text { al. } 2017^{* 15}\end{array}$ & $\begin{array}{l}\text { Randomized } \\
\text { control study, } \\
\text { double blind, } \\
\text { parallel group }\end{array}$ & $\begin{array}{l}129 \text { alcohol- } \\
\text { dependent } \\
\text { male smokers, } \\
\text { aged 18-70 } \\
\text { years }\end{array}$ & $\begin{array}{l}\text { 12-week } \\
\text { clinical } \\
\text { trial }\end{array}$ & $\begin{array}{l}63 \text { participants taking } \\
\text { topiramate up to } 200 \mathrm{mg} \text { daily } \\
\text { divided into doses: first in } 25 \\
\text { mg increments (weeks } 1-4 \text { ) } \\
\text { and then in } 50 \mathrm{mg} \text { increments } \\
\text { (weeks } 5-6 \text { ) }\end{array}$ & $\begin{array}{l}66 \\
\text { participants } \\
\text { taking } \\
\text { placebo } \\
\text { orally }\end{array}$ & $\begin{array}{l}\text { Biochemically } \\
\text { confirmed } \\
\text { 4-week } \\
\text { continuous } \\
\text { abstinence } \\
\text { from smoking } \\
\text { during weeks } \\
\text { 9-12 }\end{array}$ & $\begin{array}{l}\text { 7-day point } \\
\text { prevalence } \\
\text { smoking } \\
\text { abstinence } \\
\text { rates during } \\
\text { treatment } \\
\text { (weeks 6-12) }\end{array}$ \\
\hline $\begin{array}{l}\text { Oncken et al. } \\
2014^{17}\end{array}$ & $\begin{array}{l}\text { Randomized } \\
\text { control study, } \\
\text { double blind }\end{array}$ & $\begin{array}{l}57 \\
\text { participants } \\
\text { who smoked } \\
\text { at least } 10 \\
\text { cigarettes/day } \\
\text { during the } \\
\text { past year }\end{array}$ & $\begin{array}{l}\text { 10-week } \\
\text { clinical } \\
\text { trial }\end{array}$ & $\begin{array}{l}19 \text { participants started at the } \\
\text { baseline visit and the dosage } \\
\text { was titrated up over } 5 \text { weeks } \\
\text { ( } 25 \mathrm{mg} / \text { day for } 1 \text { week, } 25 \mathrm{mg} \\
\text { twice daily for } 1 \text { week, } 50 \mathrm{mg} \\
\text { twice daily for } 1 \text { week, } 75 \mathrm{mg} \\
\text { twice daily for } 1 \text { week, and } 100 \\
\text { mg twice daily for } 5 \text { weeks) }\end{array}$ & $\begin{array}{l}19 \\
\text { participants } \\
\text { taking } \\
\text { placebo } \\
\text { orally }\end{array}$ & $\begin{array}{l}\text { The last } \\
\text { 4-week } \\
\text { continuous } \\
\text { abstinence } \\
\text { rates and CO- } \\
\text { confirmed }\end{array}$ & $\begin{array}{l}\text { Weekly } \\
\text { abstinence } \\
\text { rates, } \\
\text { 7-day point } \\
\text { prevalence } \\
\text { confirmed by } \\
\text { exhaled C0 } \\
\leq 10 \text { ppm, by } \\
\text { treatment } \\
\text { weeks } 2-10\end{array}$ \\
\hline $\begin{array}{l}\text { Johnson et al. } \\
2005^{14}\end{array}$ & $\begin{array}{l}\text { Randomized } \\
\text { control trial, } \\
\text { double blind }\end{array}$ & $\begin{array}{l}94 \text { alcohol } \\
\text { dependent } \\
\text { who reported } \\
\text { smoking } \geq 1 \\
\text { cigarettes/ } \\
\text { day, aged } \\
21-65 \text { years }\end{array}$ & $\begin{array}{l}\text { 12-week } \\
\text { clinical } \\
\text { trial }\end{array}$ & $\begin{array}{l}45 \text { participants taking } \\
\text { topiramate up to } 300 \mathrm{mg} \text { daily } \\
\text { divided into doses, first in } 25 \\
\text { mg increments (weeks } 1-4 \text { ), } \\
\text { and then in } 50 \mathrm{mg} \text { increments } \\
\text { (weeks } 5-8 \text { ) }\end{array}$ & $\begin{array}{l}49 \\
\text { participants } \\
\text { taking } \\
\text { placebo } \\
\text { orally }\end{array}$ & & $\begin{array}{l}\text { Weekly } \\
\text { self-reported } \\
\text { cigarette } \\
\text { smoking at } \\
\text { weeks } 0,3,6 \text {, } \\
9 \text { and } 12\end{array}$ \\
\hline $\begin{array}{l}\text { Anthenelli et } \\
\text { al. } 2008^{16}\end{array}$ & $\begin{array}{l}\text { Randomized } \\
\text { control trial, } \\
\text { double blind }\end{array}$ & $\begin{array}{l}77 \text { chronic } \\
\text { smokers who } \\
\text { smoked on } \\
\text { average }>10 \\
\text { cigarettes/day }\end{array}$ & $\begin{array}{l}\text { 11-week } \\
\text { clinical } \\
\text { trial }\end{array}$ & $\begin{array}{l}43 \text { topiramate up to a } \\
\text { maximum dose of } 200 \mathrm{mg} \text { daily } \\
\text { in twice-daily divided doses. } \\
\text { Topiramate was started at } 25 \\
\mathrm{mg} \text {, taken at bedtime, and } \\
\text { increased by } 25 \mathrm{mg} / \text { day each } \\
\text { week (weeks } 1-4 \text { ) or } 50 \mathrm{mg} / \\
\text { day each week during weeks } \\
5 \text { and } 6 \text { until } 200 \mathrm{mg} / \text { day was } \\
\text { reached at week } 6\end{array}$ & $\begin{array}{l}44 \\
\text { participants } \\
\text { taking } \\
\text { placebo } \\
\text { orally }\end{array}$ & $\begin{array}{l}\text { Carbon } \\
\text { monoxide } \\
\text { confirmed } \\
\text { 4-week } \\
\text { prolonged } \\
\text { abstinence } \\
\text { rate during } \\
\text { weeks 8-11 }\end{array}$ & \\
\hline $\begin{array}{l}\text { Liang et al. } \\
2008^{* * 13}\end{array}$ & $\begin{array}{l}\text { Non- } \\
\text { randomized } \\
\text { control trial }\end{array}$ & $\begin{array}{l}99 \text { patients } \\
\text { with } \\
\text { depression }\end{array}$ & $\begin{array}{l}\text { 12-week } \\
\text { clinical } \\
\text { trial }\end{array}$ & $\begin{array}{l}50 \text { participants taking } \\
\text { topiramate } 200 \mathrm{mg} / \text { day from } \\
\text { weeks } 1-4 \text {, and then decreased } \\
\text { progressively from the } 5 \text { th } \\
\text { week, and finally discontinued } \\
\text { at the end of the } 8 \text { th week }\end{array}$ & $\begin{array}{l}49 \\
\text { participants } \\
\text { taking } \\
\text { placebo } \\
\text { orally }\end{array}$ & & $\begin{array}{l}\text { Quit success } \\
\text { rate, } \leq 1 \\
\text { cigarettes/day } \\
\text { considered as } \\
\text { a successful } \\
\text { quit, for } \\
\text { weeks } 2,4,6 \text {, } \\
8 \text { and } 12\end{array}$ \\
\hline
\end{tabular}

* All participants received manual-guided smoking cessation counseling combined with medication-focused compliance enhancement therapy.

** All participants treated with antidepressants and cognitive-behavioral interventions.

abstinence in the topiramate-treated group at weeks On the other hand, the pooled odds ratios at weeks 2 , 4, 6, 8 and 12 were significant ( $\mathrm{OR}=3.07,95 \%$ CI: $\quad 3,7,9$ and 10 were not significant $(\mathrm{OR}=1.42,95 \%$ CI: 1.19-7.93; $\mathrm{OR}=4.03,95 \%$ CI: $1.98-8.2 ; \mathrm{OR}=2.29, \quad 0.43-4.73 ; \mathrm{OR}=1.46,95 \%$ CI: $0.48-4.45 ; \mathrm{OR}=2.37$, 95\% CI: $1.23-4.28$; OR=2.45, 95\% CI: $1.37-4.39$; 95\% CI: $0.81-6.98$; OR=1.4, 95\% CI: $0.72-2.73$; respectively) compared with the control (Figure 3). $\mathrm{OR}=1.29,95 \%$ CI: 0.61-2.73; respectively). The Q 
Figure 2. Forest plot for 4 -week smoking abstinence rate

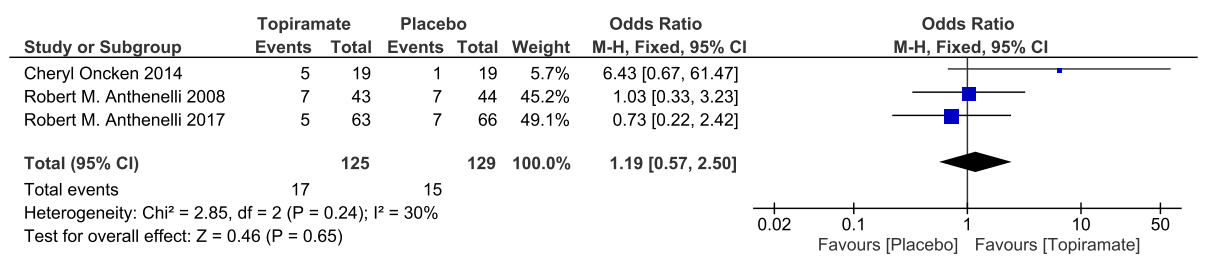

Figure 3. Forest plot for all time-points meta-analysis (ATM) of smoking abstinence rate

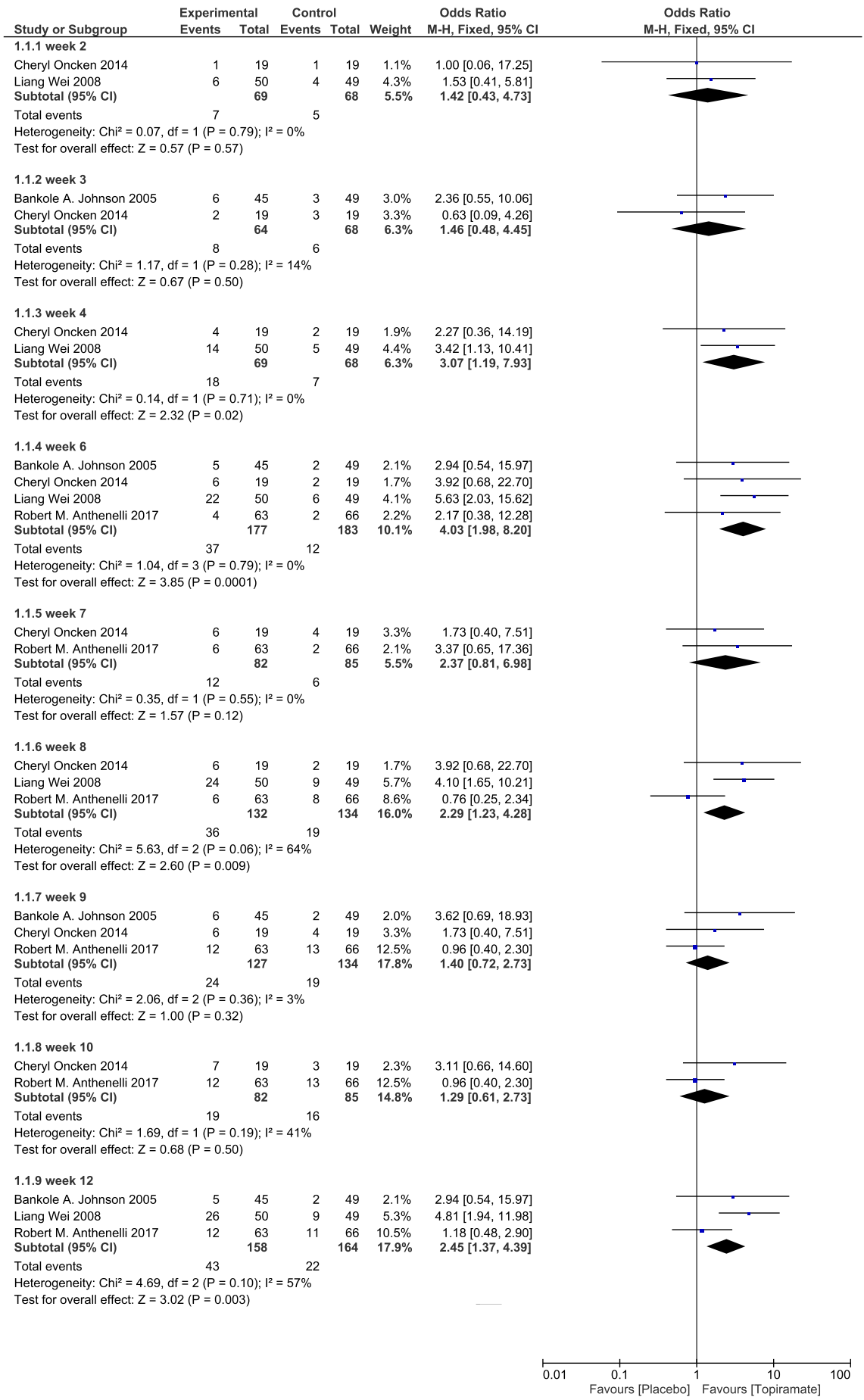


Figure 4. Sensitivity analysis for all time-points meta-analysis (ATM) of smoking abstinence rate after excluding the low-quality study

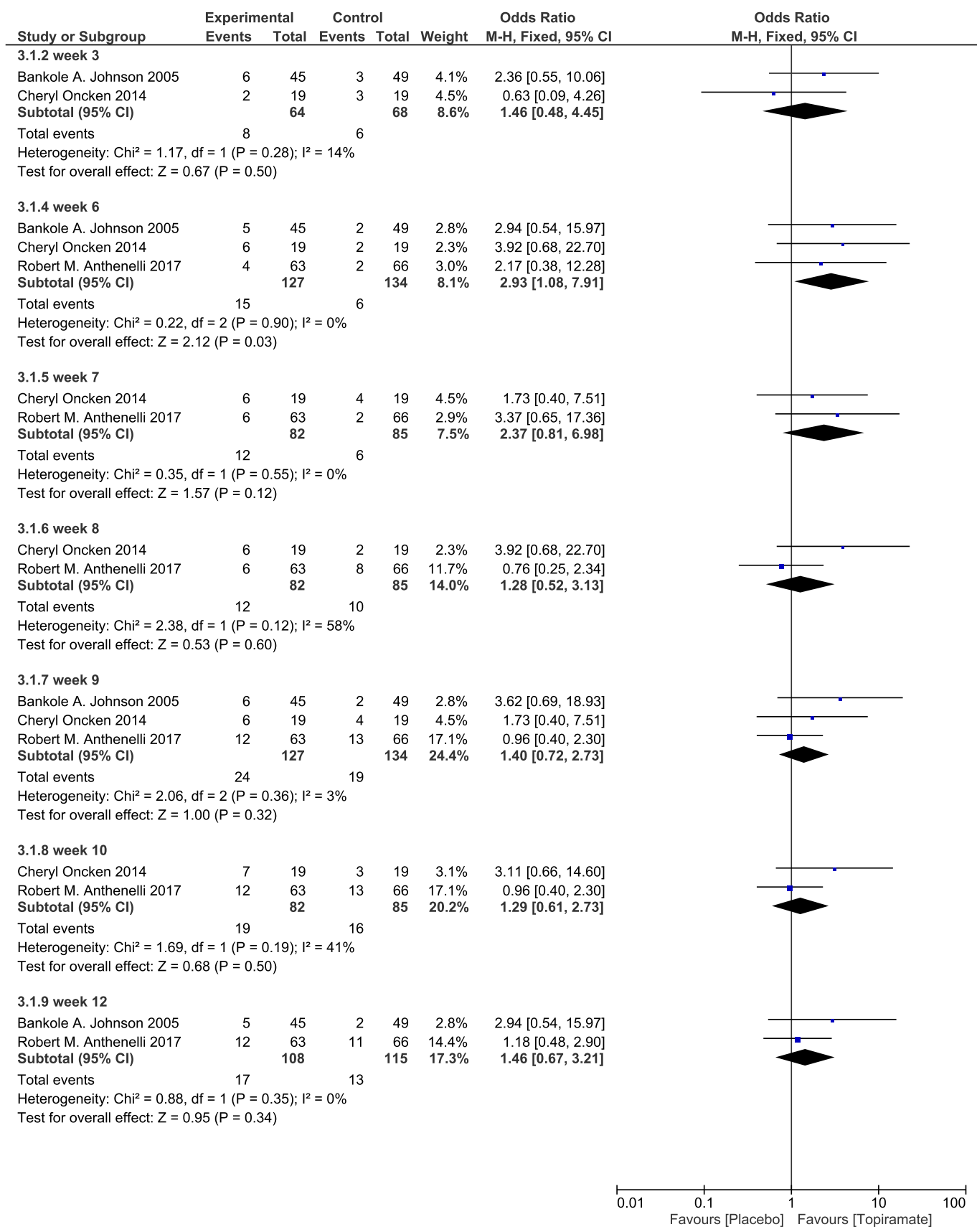

statistic did not show significant heterogeneity for any of the time points.

Sensitivity analysis was conducted by excluding the low-quality study ${ }^{13}$ and it was found that the pooled odds ratio of topiramate had a statistically significant effect at week $6(\mathrm{OR}=2.93$, CI: $1.08-$ 7.91). The $Q$ statistic did not show significant heterogeneity for any of the time points (Figure 4).

\section{DISCUSSION}

Smoking is a worldwide health problem and many efforts have been made to reduce it. Only three pharmacotherapies are approved by the FDA for smoking cessation: nicotine replacement therapy, bupropion $^{18}$ and varenicline ${ }^{19}$. Other medications that are not FDA-approved but which showed efficacy in clinical trials are nortriptyline $e^{20}$ and 
clonidine $^{21}$. Behavioral therapy in combination with pharmacotherapy increases the smoking quit rate compared with pharmacotherapy alone ${ }^{22}$. The recommended first-line for smoking cessation by the American College of Cardiology is varenicline or a combination of nicotine replacement therapy; the second-line is topiramate, a well-tolerated antiepileptic drug ${ }^{23,24}$ that has shown some benefits in smoking cessation in a few clinical trials. The question is, however, what are the reliable measures for effectiveness of a treatment to enhance smoking cessation and for how long? An ongoing clinical trial is comparing varenicline and bupropion ${ }^{25}$. The primary outcome is smoking prevalence and continuous smoking abstinence, biochemically confirmed by salivary cotinine after $4,8,12,26$ and 52 weeks of starting a 12 -week treatment. A new meta-analysis examined efficacy of varenicline for smoking cessation in schizophrenia ${ }^{25}$. The outcome measures were: number of cigarettes and CO level over the treatment period up to 3 months. A recent trial measured the abstinence rate after 12 months of starting varenicline treatment ${ }^{26}$. In the present meta-analysis, the reported prolonged abstinence rates were measured during the last 4 weeks of starting the treatment, which may underestimate the effect of topiramate, and we did not have a long follow-up period after the treatment weeks, except in one study ${ }^{15}$ that had a 24-week follow-up without measuring outcomes. Additionally, the total sample size of the three studies used for pooling effect size of prolonged abstinence rate was 125 topiramate-treated smokers and 129 controls, which may be still underpowered to show significant difference, although the numeric difference favors topiramate. Time point prevalence was also reported as a measure for smoking abstinence rate. A recent placebo-controlled randomized clinical trial tested the efficacy and safety of varenicline in smokers with $\mathrm{HIV}^{27}$. Point prevalence abstinence at weeks 12 and 24 was used as a primary outcome. The pooled time point abstinence rate at week 12 was significantly higher in the topiramate group when compared with the control, which is the pooled effect of three studies and may be more representative than time point prevalence at earlier weeks. The major side effects of topiramate, as reported by the manufacturer, are paresthesia, fatigue, dizziness, decrease serum bicarbonate, hyperammonemia, abdominal pain, nephrolithiasis and disturbance in attention. The topiramate dose based on the available studies is 200 $\mathrm{mg}$, started with a small dose and titrated slowly to the reported dose up to 12 weeks.

\section{Limitations}

There are some limitations in the current study. Firstly, it involves only clinical trial studies with only topiramate as an intervention for smoking cessation. Secondly, due to the insufficient number of the included studies, the publication bias and subgroup analysis cannot be performed. Thirdly, we were working on all possible outcomes regarding the effectiveness of topiramate on smoking cessation compared with the placebo and found the following outcomes:

- Prolonged smoking abstinence rates were reported in three studies ${ }^{15-17}$ and all were included in metaanalysis.

- Time point abstinence rates were reported in four studies ${ }^{13-15,17}$ and all were included in metaanalysis.

- Cotinine level was reported in 2 studies: one dichotomized it into two categories: below and above $28 \mathrm{ng} / \mathrm{mL}$, to discriminate between smokers and non-smokers ${ }^{14}$. The other study measured cotinine level at baseline only to show difference between males and females ${ }^{16}$. The combinability of the results is invalid.

- Number of cigarettes was reported in 3 studies: in the first, the mean number of cigarettes smoked at the end of the treatment among topiramate group was $16.2( \pm 11.21 \mathrm{SD})$ while among the placebo it was $21.93( \pm 7.11 \mathrm{SD})^{28}$. The second represented means of cigarettes per week graphically without SD over the 12-week treatment with topiramate and during the 24 -week follow-up period ${ }^{29}$. In the third, the average cigarettes across the topiramate group decreased from a mean of 19.2 cigarettes/ day $( \pm 7.5 \mathrm{SD})$ to 6.7 cigarettes/day $( \pm 6.8 \mathrm{SD})$, with no data for placebo ${ }^{30}$. The combinability of the results is invalid.

\section{CONCLUSIONS}

The efficacy of topiramate in promoting smoking cessation, based on the available evidence, could not be established. We cannot recommend topiramate for smoking cessation in practice. A large clinical trial 
with sufficient power is required with longer followup times to demonstrate the efficacy of topiramate in smoking cessation.

\section{REFERENCES}

1. Mokdad AH, Marks JS, Stroup DF, Gerberding JL. Actual causes of death in the United States, 2000. JAMA. 2004;291(10):1238-1245. doi:10.1001/jama.291.10.1238

2. National Center for Chronic Disease Prevention and Health Promotion (US) Office on Smoking and Health. The health consequences of smoking-50 years of progress: a report of the Surgeon General. Atlanta (GA): Centers for Disease Control and Prevention (US); 2014. doi:10.1111/dar.12309

3. Langtry HD, Gillis JC, Davis R. Topiramate. Drugs. 1997;54(5):752-773. doi:10.2165/00003495-199754050-00009

4. Marcotte D. Use of topiramate, a new anti-epileptic as a mood stabilizer. J Affect Disord. 1998;50(2-3):245-251. doi:10.1016/s0165-0327(98)00110-4

5. Appolinario JC, Fontenelle LF, Papelbaum M, Bueno JR, Coutinho W. Topiramate use in obese patients with binge eating disorder: an open study. Can J Psychiatry. 2002;47(3):271-273. doi:10.1177/070674370204700309

6. Diener HC, Tfelt-Hansen P, Dahlöf C, et al. Topiramate in migraine prophylaxis. Journal of Neurology. 2004;251(8):943-950. doi:10.1007/s00415-004-0464-6

7. Johnson BA, Ait-Daoud N, Wang X-Q, et al. Topiramate for the treatment of cocaine addiction: a randomized clinical trial. JAMA Psychiatry. 2013;70(12):1338-1346. doi:10.1001/jamapsychiatry.2013.2295

8. Kampman KM, Pettinati HM, Lynch KG, Spratt K, Wierzbicki MR, O’Brien CP. A double-blind, placebocontrolled trial of topiramate for the treatment of comorbid cocaine and alcohol dependence. Drug Alcohol Depend. 2013;133(1):94-99. doi:10.1016/j.drugalcdep.2013.05.026

9. Miranda Jr R, Treloar H, Blanchard A, et al. Topiramate and motivational enhancement therapy for cannabis use among youth: a randomized placebo-controlled pilot study. Addict Biol. 2017;22(3):779-790. doi:10.1111/adb.12350

10. Schulz KF, Altman DG, Moher D. CONSORT 2010 Statement: updated guidelines for reporting parallel group randomised trials. BMJ. 2010;340(1):c332-c332. doi:10.1136/bmj.c332

11. Higgins JPT, Altman DG, Gotzsche PC, et al. The Cochrane Collaboration's tool for assessing risk of bias in randomised trials. BMJ. 2011;343(2):d5928-d5928. doi;10.1136/bmj.d5928

12. Peters JL, Mengersen KL. Meta-analysis of repeated measures study designs. J Eval Clin Pract. 2008;14(5):941950. doi:10.1111/j.1365-2753.2008.01010.x

13. Liang W, Zhang HM, Zhang HY. [Smoking cessation efficacy of topiramate in patients with depression]. Chinese Journal of New Drugs and Clinical Remedies. $2008 ; 12$.
14. Johnson BA, Ait-Daoud N, Akhtar FZ, Javors MA. Use of oral topiramate to promote smoking abstinence among alcohol-dependent smokers: a randomized controlled trial. Arch Intern Med. 2005;165(14):1600-1605. doi:10.1001/archinte.165.14.1600

15. Anthenelli RM, Heffner JL, Wong E, et al. A randomized trial evaluating whether topiramate aids smoking cessation and prevents alcohol relapse in recovering alcoholdependent men. Alcohol Clin Exp Res. 2017;41(1):197206. doi:10.1111/acer.13279

16. Anthenelli RM, Blom TJ, McElroy SL, Keck PE. Preliminary evidence for gender-specific effects of topiramate as a potential aid to smoking cessation. Addiction. 2008;103(4):687-694. doi:10.1111/j.1360-0443.2008.02148.x

17. Oncken C, Arias AJ, Feinn R, et al. Topiramate for smoking cessation: a randomized, placebo-controlled pilot study. Nicotine Tob Res. 2013;16(3):288-296. doi:10.1093/ntr/ntt141

18. Syed BA, Chaudhari K. Smoking cessation drugs market. Nature Publishing Group. 2013;12(2):97-98. doi:10.1038/nrd3914

19. Moore TJ, Singh S, Furberg CD. The FDA and new safety warnings. Arch Intern Med. 2012;172(1):78-80. doi:10.1001/archinternmed.2011.618

20. Hughes JR, Stead LF, Lancaster T. Nortriptyline for smoking cessation: a review. Nicotine Tob Res. 2005;7(4):491-499. doi:10.1080/14622200500185298

21. Gourlay SG, Stead LF, Benowitz N. Clonidine for smoking cessation. Cochrane Database Syst Rev. 2004;(3):CD000058. doi:10.1002/14651858.cd000058

22. Stead LF, Koilpillai P, Fanshawe TR, Lancaster T. Combined pharmacotherapy and behavioural interventions for smoking cessation. Cochrane Database Syst Rev. 2016(3):CD008286. doi:10.1002/14651858.CD008286.pub2

23. Jones M. Topiramate-safety and tolerability. Can J Neurol Sci. 1998;25(3):S13-S15. doi:10.1017/s0317167100034855

24. Shorvon SD. Safety of topiramate: adverse events and relationships to dosing. Epilepsia. 1996;37:S18-S22. doi:10.1111/j.1528-1157.1996.tb06029.x

25. Zawertailo L, Mansoursadeghi-Gilan T, Zhang H, Hussain S, Le Foll B, Selby P. Varenicline and Bupropion for Long-Term Smoking Cessation (the MATCH Study): Protocol for a Real-World, Pragmatic, Randomized Controlled Trial. JMIR Res Protoc. 2018;7(10):e10826. doi:10.2196/10826

26. Zenteno RJH, Lara DF, Venegas AR, et al. Varenicline for long term smoking cessation in patients with COPD. Pulm Pharmacol Ther. 2018;53:116-120. doi:10.1016/j.pupt.2018.11.001

27. Ashare RL, Thompson M, Serrano K, et al. Placebo-controlled randomized clinical trial testing the efficacy and safety of varenicline for smokers with HIV. Drug Alcohol Depend. 2019;200:26-33. doi:10.1016/j.drugalcdep.2019.03.011

28. Baltieri DA, Daró FR, Ribeiro PL, de Andrade AG. Effects of topiramate or naltrexone on tobacco 
use among male alcohol-dependent outpatients. Drug Alcohol Depend. 2009;105(1-2):33-41. doi:10.1016/j.drugalcdep.2009.05.025

29. Isgro M, Doran N, Heffner JL, et al. Type A/Type B alcoholism predicts differential response to topiramate in a smoking cessation trial in dually diagnosed men. J Stud Alcohol Drugs. 2017;78(2):232-240. doi:10.15288/jsad.2017.78.232

30. Worley MJ, Isgro M, Heffner JL, Lee SY, Daniel BE, Anthenelli RM. Predictors of reduced smoking quantity among recovering alcohol dependent men in a smoking cessation trial. Addict Behav. 2018;84:263-270. doi:10.1016/j.addbeh.2018.05.004

31. Weinberger AH, George TP, Perkins KA, Chengappa KR. Effects of topiramate on smoking in patients with schizoaffective disorder, bipolar type. J Clin Psychopharmacol. 2008;28(2):247-248. doi:10.1097/jcp.0b013e31816740cf

32. Vaughan B, Mariani JJ, Pavlicova M, et al. Secondary analysis of smoking rates from a double-blind, placebocontrolled clinical trial of mixed-amphetamine salts and topiramate for cocaine dependence. Drug Alcohol Depend. 2015;100(146):e10. doi:10.1016/j.drugalcdep.2014.09.709

33. Campayo JG, Sobradiel N, Alda M, et al. Effectiveness of topiramate for tobacco dependence in patients with depression; a randomised, controlled trial. BMC Fam Pract. 2008;9(1):28. doi:10.1186/1471-2296-9-28

34. Reid MS, Palamar J, Raghavan S, Flammino F. Effects of topiramate on cue-induced cigarette craving and the response to a smoked cigarette in briefly abstinent smokers. Psychopharmacology. 2007;192(1):147-158. doi:10.1007/s00213-007-0755-6

35. Sofuoglu M, Poling J, Mouratidis M, Kosten T. Effects of topiramate in combination with intravenous nicotine in overnight abstinent smokers. Psychopharmacology. 2006;184(3-4):645-651. doi:10.1007/s00213-005-0296-9

36. Khazaal Y, Cornuz J, Bilancioni R, Zullino DF. Topiramate for smoking cessation. Psychiatry Clin Neurosci. 2006;60(3):384388. doi:10.1111/j.1440-1819.2006.01518.x
CONFLICTS OF INTEREST

The authors have completed and submitted the ICMJE Form for Disclosure of Potential Conflicts of Interest and none was reported.

FUNDING

There was no source of funding for this research.

AUTHORS' CONTRIBUTIONS

Search idea: HE. Search strategy and selection criteria: HE and NL. Risk of bias assessment: HE and NL. Meta-analysis: HE and NL. All time-points meta-analysis (ATM) : NL. Writing up of original draft: HE and NL. Review: $\mathrm{MH}$. Writing the final manuscript: NL.

PROVENANCE AND PEER REVIEW

Not commissioned; externally peer reviewed. 